Mauro Meirelles

Doutorando em Antropologia Social

PPGAS-UFRGS

\title{
WYNARCZYK, HILÁRIO. CIUDADANOS DE DOS MUNDOS: EL MOVIMIENTO EVANGÉLICO VIDA PÚBLICA ARGENTINA 1980-2001. BUENOS AIRES: UNSAM EDITA, 2009. 329 P.
}

O livro "Ciudadanos de dos mundos: el movimiento evangélico vida pública argentina 1980-2001”, Hilário Wynarczyk nos brinda com um exaustivo mapeamento acerca da forma como se deu a entrada de diversos grupos evangélicos conservadores na arena pública argentina em função da garantia da igualdade e liberdade de culto num país que constitucionalmente se declara católico. Sobretudo, em seu texto o autor busca responder a duas questóes fundamentais: a primeira que busca mapear/compreender as razóes/elementos que levaram esses grupos, notadamente alheios a arena pública, a abandonar seu isolamento ascético dado por seu sistema de crenças e ingressar na esfera pública; e, a segunda, que busca determinar, no tempo e no espaço, o momento em que efetivamente se dá o abandono dessa conduta pietista e, estes, passam efetivamente a participar da esfera pública em função de interesses que, no limite, podem chegar ao ideário de construção e formação de um partido político evangélico.

No capítulo 1, a título de uma breve introdução, o autor inicia seu transcurso de pesquisa expondo alguns de seus referenciais teóricos tais como a idéia de campo de força, forças em conflito e a forma como apreende o segmento evangélico em sua pesquisa. Ainda no que se refere a forma como percebe o seu objeto de pesquisa tem-se que este se utiliza da ótica de teoria dos sistemas para olhar o outro com o qual se ocupa em seu trabalho investigativo. Este, um outro polarizado entre duas posições distintas, a do pólo histórico liberacionista e a do pólo dos conservadores bíblicos. Outrossim,

Debates do NER, Porto Alegre, ANo io, N. I6, P. 263-265, JUl./Dez. 2009 
dá especial destaque a sua inserção no campo e a forma como teve acesso aos dados e as fontes que se utiliza no decorrer dos capítulos subseqüentes com as quais, se ocupa de forma exaustiva no transcorrer de toda a obra.

Já, no capítulo 2 intitulado "El campo evangélico argentino hasta la década de 1970: formación y dinámica”, Wynarczyk se ocupa mais especificamente da forma como se deu a constituição do campo evangélico argentino até 1980 buscando destacar, sobretudo, a grande heterogeneidade interna que faz parte se sua própria constituição histórica. Neste sentido, deixa evidente as relaçóes que esse segmento manteve como o peronismo e a forma como essa relação, de certa forma instrumental, mantida por Péron com o segmento evangélico serviu, até certo ponto, como uma forma deste segmento romper com algumas barreiras institucionais existentes, ao mesmo tempo em que, a Péron para afrontar os católicos que a ele se opunham.

O capítulo 3 que traz o título "El Evangelio de poder" da mesma forma que o capítulo anterior tem como foco realizar o mapeamento das diversas teologias existentes no campo evangélico ao mesmo tempo em que, avalia o impacto que mudanças trazidas pelo pentecostalismo e o início das campanhas Argentina para Cristo iniciadas por Carlos Annacondia tiveram no surgimento de um novo marco interpretativo e de sentido que permitira aos evangélicos argentinos incorporar novos elementos ao seu conjunto de crenças $^{1}$ que se fizeram presentes através de diversos predicadores neopentecostais e da formação de mega-igrejas que funcionam como grandes nós autóctones e independentes de outras denominaçóes que compóem o campo evangélico argentino. Realizado esse mapeamento do campo evangélico argentino, os atores envolvidos e os conceitos a serem utilizados no decorrer do texto, é o momento de, nos capítulos seguintes iniciar sua análise.

Isto posto, temos então que o autor divide o capítulo 4, intitulado "Crecimento y Amenaza" em duas partes. Uma primeira dedicada ao "Crescimento" onde realiza um mapeamento da forma como se deu o crescimento de uma minoria religiosa, essa pentecostal, que a partir dos anos 1980 toma

${ }^{1}$ Tais como o ideário da Guerra Espiritual, da Teologia da Prosperidade, a Conquista de Cidades e a Unção Fresca, entre outros.

Debates do NER, Porto Alegre, Ano io, N. 16, P. 263-265, JUl./Dez. 2009 
espaço na cena buenarense de modo que, é a partir dos anos de 1990 que, tanto os evangélicos conservadores bíblicos como os neopentecostais se farão mais presentes na esfera pública religiosa, em especial, no que se refere ao seu crescimento nas listas da Secretaria Nacional de Cultos e sua presença mais significativa na Província de Buenos Aires, incluindo o Conurbado Buenarense e a Capital Federal. E outra, que busca mostrar a forma como esse crescimento foi interpretado por outros setores da sociedade argentina como uma "Ameaça" ao stablishment católico que buscava barrar esse crescimento evangélico.

Do campo religioso e depois de apontados os principais enfrentamentos que se faziam presente entre diferentes atores religiosos na cena pública, o autor, no capítulo 5, intitulado "Del pánico moral a la arena jurídica", passa a análise da forma como se deu esse embate no plano jurídico em razão da forma diferenciada como eram tratados evangélicos e católicos em função de privilégios históricos. É da forma como se deu esse enfrentamento e dos lugares que ocuparam nessa vendeta a Igreja Católica, os Evangélicos, os Intelectuais e o próprio Estado argentino, através do Registro Nacional de Cultos, do Executivo e do Legislativo que se ocupará o autor até o início do capítulo 6. Neste capítulo, que por si só, por seu título "El movimento social strictu sensu", já evidencia o ponto de vista defendido pelo autor durante todo o livro este situa o movimento evangélico argentino e toda a movimentação decorrente de sua institucionalização como um movimento social em si que adentra a cena pública na busca de direitos e igualdade de tratamento frente a burocracia estatal argentina, como deixa evidente em capítulos anteriores. E deste modo, encerra o livro, com uma breve conclusão onde avalia a aplicabilidade do modelo de análise por ele proposto a partir dos referenciais por ele apresentados no capítulo 1 .

Debates do NER, Porto Alegre, ANo io, N. I6, P. 263-265, JUl./Dez. 2009 